\title{
TELMISARTAN AND AZELNIDIPINE QUANTIFICATION EMPLOYING HPLC STRATAGEM; STABILITY INVESTIGATION ON TELMISARTAN AND AZELNIDIPINE
}

\author{
K. V. L. D. SPANDANA, N. J. P. SUBHASHINI*
}

Department of Pharmacy, University College of Technology, Osmania University, Hyderabad, India

Email: njsubhashini@yahoo.co.in

Received: 06 Oct 2021, Revised and Accepted: 17 Nov 2021

\section{ABSTRACT}

Objective: The focus of our research was to create a fairly sensitive HPLC stratagem for determining telmisartan (TLM) and azelnidipine (AEL) in bulk and tablet types.

Methods: Analysis of TLM and AEL was performed on a "C18 Kromasil stationary column (5 $\mu \mathrm{m}, 250 \mathrm{~mm} \times 4.6 \mathrm{~mm}$ )". The mobile phase was made of $0.1 \mathrm{M} \mathrm{NaH}_{2} \mathrm{PO}_{4}$ solution ( $\mathrm{pH} 3.5$ ) and methanol at a comparative volume ratio of $50 \%$ each. The analysis of TLM and AEL was isocratic, with the flow velocity adjusted at $1.0 \mathrm{ml} / \mathrm{min}$ and indeed, the TLM and AEL analysis was done at $256 \mathrm{~nm}$ using a PDA device sensor. TLM and AEL were stressed with acid, peroxide, dry heat, alkali, and sunlight-induced settings.

Results: The retention/elution periods for the TLM and AEL were observed at 2.225 min and 3.178 min, respectively. The HPLC stratagem developed have a straight-line relation with relative concentrations in the ranges of 20-60 $\mu \mathrm{g} / \mathrm{ml}$ for TLM and 4-12 $\mu \mathrm{g} / \mathrm{ml}$ for AEL. The LOQ's for TLM and AEL were $0.2516 \mu \mathrm{g} / \mathrm{ml}$ and $0.0871 \mu \mathrm{g} / \mathrm{ml}$, respectively. The validation investigational findings done for TLM and AEL with the established sensitive HPLC stratagem were passed out in conformity with the ICH standards.

Conclusion: The established sensitive HPLC stratagem was shown as competent for the quality check of bulk samples of TLM and AEL throughout batch release as well as in the course of TLM and AEL stability investigations.

Keywords: Telmisartan, Azelnidipine, Hypertension, Stability investigation, HPLC

(C) 2022 The Authors. Published by Innovare Academic Sciences Pvt Ltd. This is an open access article under the CC BY license (https://creativecommons.org/licenses/by/4.0/] DOI: https://dx.doi.org/10.22159/ijap.2022v14i1.43321. Journal homepage: https://innovareacademics.in/journals/index.php/ijap

\section{INTRODUCTION}

Telmisartan (TLM), fig. 1, is a blocker for angiotensin II receptor with remarkable pharmacologic qualities, including that of the greatest half-life of all blockers of angiotensin II receptors. This results in a considerable and long-lasting decrease in blood pressure of up to $24 \mathrm{~h}$ [1-3]. TLM possesses antihypertensive characteristics, although there exists excellent clinical proof that it decreases the stiffness of arteries, left ventricular hypertrophy, and atrial fibrillation recurrence, as well as imparting renoprotection.
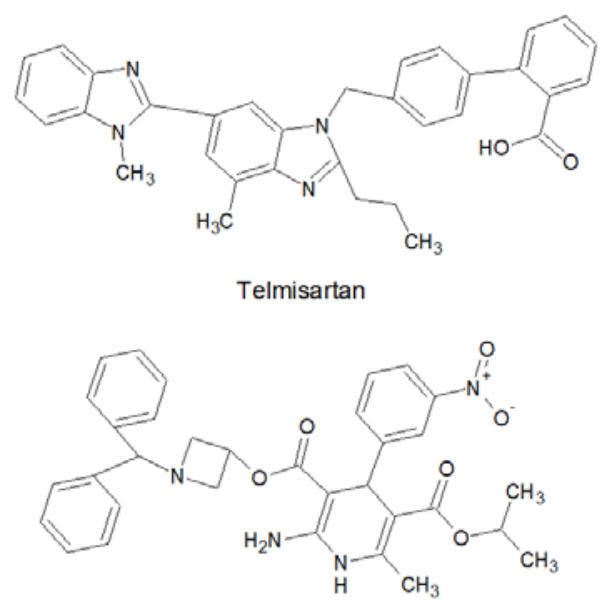

Azelnidipine

Fig. 1: TLM and AEL structures

Azelnidipine (AEL) is a lengthy-acting dihydropyridine antagonist for the calcium channel of the $3^{\text {rd }}$ generation. AEL has been shown to have a beneficial antihypertensive impact on individuals having essential hypertension in a number of studies [4]. AEL induces nitric oxide generation and improves histologic procedures that are important for proper wound healing in diabetic wounds [5]. AEL acts as renoprotective, in hypertension individuals with milder chronic renal disease, and this benefit is attributed, at least partly, to its anti-oxidant properties [6].

Hypertension sufferers are prescribed with the mix of TLM plus AEL. The combo of TLM and AEL regulates blood pressure among hypertension individuals while simultaneously enhancing oxygen circulation in the body, barring the risk of heart-related chest discomfort [7]. TLM with AEL are accessible in tablet formulations with strength of $80 \mathrm{mg}$ and $8 \mathrm{mg}$ of TLM as well as AEL also TLM-40 mg with AEL-8 mg, respectively.

For the assessment of TLM and AEL combo in tablets, just few techniques focused on UV spectrophotometer (provided by Yuvasri et al.,) [8] and HPLC (provided by Kumar et al., Kishore et al., and Parikh et al.,) [9-11] have been disclosed. The method of UV spectrophotometry provided by Yuvasri et al., [8] quantified TLM and AEL combo with a quantification limit of $6.018 \mu \mathrm{g} / \mathrm{ml}$ (TLM) and $0.594 \mu \mathrm{g} / \mathrm{ml}$ (AEL). In HPLC method of Kumar et al., [9] for the TLM and AEL combo determination, the quantification limit was $33.96 \mu \mathrm{g} / \mathrm{ml}$ (TLM) and $8.35 \mu \mathrm{g} / \mathrm{ml}$ (AEL). Kishore et al., [10] HPLC method did not disclosed about quantification limit. Quantification limit of Parikh et al., [11] HPLC process was reported with a quantification limit of $6.742 \mu \mathrm{g} / \mathrm{ml}$ (TLM) and $1.305 \mu \mathrm{g} / \mathrm{ml}$ (AEL). The focus of this research was to create a relatively sensitive HPLC strategy for determining TLM and AEL in bulk and tablet types with a quantification limit measure of just under $0.5 \mu \mathrm{g} / \mathrm{ml}$.

\section{MATERIALS AND METHODS}

\section{Chemicals}

"Rainbow Pharma Training Labs", India gifted TLM and AEL drugs. Telma AZ tablets ("Glenmark Pharmaceuticals Ltd", India), having the strength of $40 \mathrm{mg}$ TLM and $8 \mathrm{mg}$ AELwas used. $\mathrm{NaH}_{2} \mathrm{PO}_{4}$, 
peroxide, $\mathrm{HCl}$ and $\mathrm{NaOH}$ were got from "SD Fine Chemicals Ltd", India. Methanol was got from "Merck India Ltd", India.

\section{HPLC system}

Analysis of TLM and AEL was implemented by deploying "Waters" 2995 model HPLC apparatus, coupled with "Waters" 2998 model detector equipment. All information about TLM and AEL chromatography was acquired employing "Waters" $2^{\text {nd }}$ version EMPOWER quantifiable investigation data managing software.

\section{Conditions for TLM and AEL evaluation}

The partition and evaluation of TLM and AEL was implemented on "C18 Kromasil stationary column $(5 \mu \mathrm{m}, 250 \mathrm{~mm} \times 4.6 \mathrm{~mm})$ " regulated at $25{ }^{\circ} \mathrm{C}$. The mobile phase exploited for TLM and AEL partition and evaluation was a mix of $0.1 \mathrm{M} \mathrm{NaH}_{2} \mathrm{PO}_{4}$ solution $(\mathrm{pH}$ 3.5 ) and methanol (ratio-50\% volume each), which was driven into "C18 Kromasil stationary column" at $1.0 \mathrm{ml}$ of flow per minute. The detection was set off in UV mode at $256 \mathrm{~nm}$.

\section{TLM and AEL solutions}

Stock TLM and AEL solutions (TLM- $400 \mu \mathrm{g} / \mathrm{ml}$; AEL- $80 \mu \mathrm{g} / \mathrm{ml}$ ) were produced through dissolving exactly $40 \mathrm{mg}$ of TLM and $8 \mathrm{mg}$ of AEL in $100 \mathrm{ml}$ of mobile phase. Working TLM and AEL solutions (TLM-40 $\mu \mathrm{g} / \mathrm{ml}$; AEL-8 $\mu \mathrm{g} / \mathrm{ml}$ ) were produced through dissolving exact stock TLM and AEL solution (TLM- $400 \mu \mathrm{g} / \mathrm{ml}$; AEL- $80 \mu \mathrm{g} / \mathrm{ml}$ ) volume in mobile phase.

\section{TLM and AEL calibration curves}

Proper volume sizes of stock TLM and AEL solution (TLM- $400 \mathrm{~g} / \mathrm{ml}$; AEL-80 g/ml) were blended with mobile solvent phase to achieve the TLM and AEL calibration ranges of $20-60$ and $4-12 \mathrm{~g} / \mathrm{ml}$, respectively. The peak response of TLM and AEL were measured over at $256 \mathrm{~nm}$ using the projected HPLC evaluation conditions. The peak response of TLM and AEL at $25 \mathrm{fm}$ was directly relative to TLM and AEL concentrations, respectively. TLM and AEL calibration graphs were generated, and the linear regression equation for each was computed.

\section{Content evaluation of TLM and AEL in the Telma AZ tablets}

Ten Telma AZ pills were precisely balanced and pulverized. A quantity of pulverized material equal to $40 \mathrm{mg}$ TLM and $8 \mathrm{mg}$ AEL was properly balanced and placed into a $100 \mathrm{ml}$ flask. The sample was then sonicated for $20 \mathrm{~min}$ after $30 \mathrm{ml}$ volume-sized mobile phase was put in. The volume $(100 \mathrm{ml})$ was accomplished with mobile phase and then filtered into $100 \mathrm{ml}$ flask. This stock Telma AZ sample has quantity of $400 \mu \mathrm{g} / \mathrm{ml} \mathrm{TLM}$ and $80 \mu \mathrm{g} / \mathrm{ml}$ AEL. The working Telma AZ solution (TLM- $40 \mu \mathrm{g} / \mathrm{ml} ;$ AEL- $8 \mu \mathrm{g} / \mathrm{ml}$ ) were produced through dissolving exact stock Telma AZ sample (TLM-400 $\mu \mathrm{g} / \mathrm{ml} ; \mathrm{AEL}-80 \mu \mathrm{g} / \mathrm{ml}$ ) volume in mobile phase. Using the projected HPLC evaluation conditions, the peak responses of TLM and AEL in working Telma AZ solution were determined over at $256 \mathrm{~nm}$. The contents of TLM and AEL in Telma AZ tablets were quantified employing generated TLM and AEL calibration graphs or their computed regression linear equations.

\section{Degradation studies}

The degradation studies on TLM and AEL were accomplished ensuing the guiding principles in ICH [12].

\section{Acid induced TLM and AEL degradation}

Properly measured volume size $(10 \mathrm{ml})$ of stock Telma AZ sample (TLM- $400 \mu \mathrm{g} / \mathrm{ml}$; AEL-80 $\mu \mathrm{g} / \mathrm{ml}$ ) was combined with $0.1 \mathrm{~N}$ HCl $(10$ $\mathrm{ml})$, sonicated (30 $\mathrm{min}$ ) at room temperature and then filtered.

\section{Alkali induced TLM and AEL degradation}

Properly measured volume size $(10 \mathrm{ml})$ of stock Telma AZ sample (TLM-400 $\mu \mathrm{g} / \mathrm{ml} ;$ AEL- $80 \mu \mathrm{g} / \mathrm{ml}$ ) was blended with $0.1 \mathrm{~N} \mathrm{NaOH} \mathrm{(10}$ $\mathrm{ml}$ ), sonicated (30 $\mathrm{min})$ at room temperature and then filtered.

\section{Peroxide induced TLM and AEL oxidation}

Stock Telma AZ sample having concentrations of $400 \mu \mathrm{g} / \mathrm{ml}$ TLM and $80 \mu \mathrm{g} / \mathrm{ml}$ AEL was prepared, then $10 \mathrm{ml}$ of that was merged with $30 \%$ peroxide $(10 \mathrm{ml})$, sonicated $(30 \mathrm{~min})$ at room temperature and then filtered.

\section{Dry heat-induced TLM and AEL degradation}

Stock Telma AZ sample $(10 \mathrm{ml})$ having concentrations of $400 \mu \mathrm{g} / \mathrm{ml}$ TLM and $80 \mu \mathrm{g} / \mathrm{ml} \mathrm{AEL}$ was positioned over an oven (thermostatically managed) at $60^{\circ} \mathrm{C}$ temperature for $30 \mathrm{~min}$ and then filtered.

\section{Sun light-induced TLM and AEL degradation}

Stock Telma AZ sample $(10 \mathrm{ml})$ having concentrations of $400 \mu \mathrm{g} / \mathrm{ml}$ TLM and $80 \mu \mathrm{g} / \mathrm{ml}$ AEL was positioned in sunlight for $6 \mathrm{hr}$ and then filtered.

The filtered acid, peroxide, dry heat, alkali, and sunlight-induced Telma AZ degraded samples were completed to volume size $100 \mathrm{ml}$ with the mobile phase. The surviving content of TLM and AEL was then ascertained using projected HPLC evaluation conditions.

\section{RESULTS}

A superior separation of TLM and AEL and balanced peak shapes for TLM and AEL were achieved on "C18 Kromasil stationary column (5 $\mu \mathrm{m}, 250 \mathrm{~mm} \times 4.6 \mathrm{~mm}$ )" regulated at $25^{\circ} \mathrm{C}$, mobile phase exploited was a mix of $0.1 \mathrm{M} \mathrm{NaH} \mathrm{PO}_{4}$ solution (pH 3.5) and methanol (ratio$50 \%$ volume each), which was driven into "C18 Kromasil stationary column" at $1.0 \mathrm{ml}$ of flow per minute. The detection was set off in UV mode at $256 \mathrm{~nm}$. Under the projected HPLC evaluation conditions, the Rt's for TLM and AEL were observed at $2.225 \mathrm{~min}$ and $3.178 \mathrm{~min}$, respectively, as made known in fig. 2 .

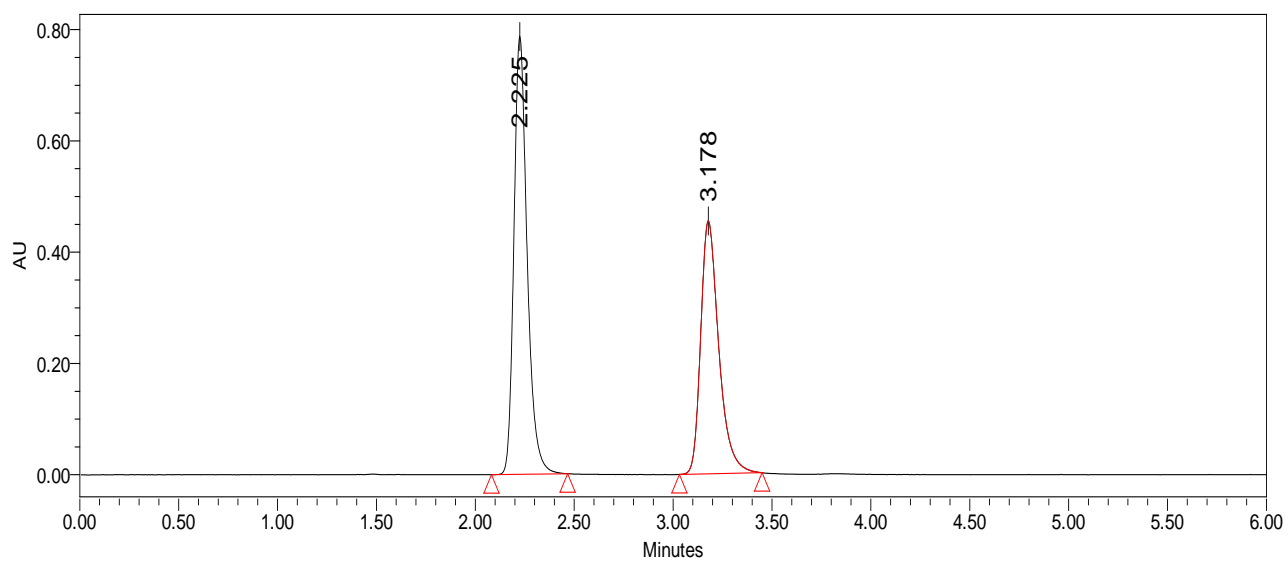

Fig. 2: TLM and AEL chromatogram projected HPLC evaluation conditions 
The validation studies for projected HPLC evaluation conditions were accomplished ensuing the guiding principles in ICH [13]

\section{Linearity}

Peak areas of TLM and AEL at $225 \mathrm{~nm}$ were showcased to have a straight-line relation with relative concentrations in the ranges of 20-60 $\mu \mathrm{g} / \mathrm{ml}$ (TLM) and 4-12 $\mu \mathrm{g} / \mathrm{ml}$ (AEL).

The equation that represents lined regression is as follows:

Peak area of TLM = 36467.17 (concentration of TLM)-17768; $R^{2}=$ 0.9999

Peak area of AEL $=29054.03$ (concentration of AEL)-13368.2; $R^{2}=$ 0.9998

\section{Sensitivity}

Sensitivity was evaluated based on 3 (for LOD) and 10 (for LOQ) standard deviations of peak area divided by the slope values in calibration curve. The LOD's for TLM and AEL were $0.0755 \mu \mathrm{g} / \mathrm{ml}$ and $0.0261 \mu \mathrm{g} / \mathrm{ml}$, respectively. While LOQ's for TLM and AEL were $0.2516 \mu \mathrm{g} / \mathrm{ml}$ and $0.0871 \mu \mathrm{g} / \mathrm{ml}$, respectively.

\section{Precision}

The repeatability of projected HPLC evaluation conditions was represented as a percent RSD from six replica investigates of working TLM and AEL solutions ( $40 \mu \mathrm{g} / \mathrm{ml}$ TLM and $8 \mu \mathrm{g} / \mathrm{ml} \mathrm{AEL)} \mathrm{to}$ characterize precision (table 1).

Table 1: TLM and AEL HPLC evaluation conditions precision

\begin{tabular}{lll}
\hline Sample injection no. & TLM \% assay & AEL \% assay \\
\hline 1 & 99.67 & 99.38 \\
2 & 99.68 & 99.51 \\
3 & 99.62 & 99.41 \\
4 & 100.10 & 99.66 \\
5 & 99.77 & 99.54 \\
6 & 100.06 & 99.84 \\
Mean* measured & 99.82 & 99.56 \\
SD measured & 0.2103 & 0.1718 \\
RSD measured & 0.211 & 0.173 \\
\hline
\end{tabular}

${ }^{*}$ Mean of 6 gauges; SD value-standard deviation for 6 gauges; RSD values-percentile standard deviation for 6 gauges

Table 2: TLM and AEL combination HPLC evaluation conditions accuracy

\begin{tabular}{|c|c|c|c|c|c|}
\hline TLM added $(\mu \mathrm{g} / \mathrm{ml})$ & TLM measured $(\mu \mathrm{g} / \mathrm{ml})$ & TLM recovered (\%) & Mean* measured (\%) & SD measured & RSD measured (\%) \\
\hline 20.000 & 19.85 & 99.26 & 99.28 & 0.2406 & 0.2424 \\
\hline 20.000 & 19.91 & 99.53 & & & \\
\hline 20.000 & 19.81 & 99.05 & & & \\
\hline 40.000 & 39.94 & 99.85 & 99.85 & 0.1050 & 0.1052 \\
\hline 40.000 & 39.98 & 99.95 & & & \\
\hline 40.000 & 39.89 & 99.74 & & & \\
\hline 60.000 & 59.85 & 99.76 & 99.82 & 0.1217 & 0.1219 \\
\hline 60.000 & 59.98 & 99.96 & & & \\
\hline 60.000 & 59.85 & 99.74 & & & \\
\hline AEL added $(\mu \mathrm{g} / \mathrm{ml})$ & AEL measured $(\mu \mathrm{g} / \mathrm{ml})$ & AEL recovered (\%) & Mean* measured (\%) & SD measured & RSD measured (\%) \\
\hline 4.000 & 3.96 & 98.93 & 99.01 & 0.5101 & 0.5152 \\
\hline 4.000 & 3.98 & 99.56 & & & \\
\hline 4.000 & 3.94 & 98.55 & & & \\
\hline 8.000 & 7.95 & 99.35 & 99.48 & 0.1353 & 0.1360 \\
\hline 8.000 & 7.96 & 99.47 & & & \\
\hline 8.000 & 7.97 & 99.62 & & & \\
\hline 12.000 & 11.96 & 99.67 & 99.82 & 0.1873 & 0.1877 \\
\hline 12.000 & 11.97 & 99.76 & & & \\
\hline 12.000 & 12.00 & 100.03 & & & \\
\hline
\end{tabular}

${ }^{*}$ Mean of 3 gauges; SD value-standard deviation for 3 gauges; RSD values-percentile standard deviation for 3 gauges

\section{Accuracy}

Investigated the accuracy with working Telma AZ sample (TLM-40 $\mu \mathrm{g} / \mathrm{ml} ; \mathrm{AEL}-8 \mu \mathrm{g} / \mathrm{ml})$ that was blended with pure TLM $(20 \mu \mathrm{g} / \mathrm{ml}, 40$ $\mu \mathrm{g} / \mathrm{ml}$ and $60 \mu \mathrm{g} / \mathrm{ml})$ and pure AEL $(4 \mu \mathrm{g} / \mathrm{ml}, 8 \mu \mathrm{g} / \mathrm{ml}$ and $12 \mu \mathrm{g} / \mathrm{ml})$ at different level concentrations. The accuracy was characterized as a percentage of TLM and AEL recovery, which was set on by comparing the added TLM and AEL concentrations to the predefined calibration curves (table 2).

\section{Degradation study}

Unknown degradation peaks (fig. 3) are examined at Rt's of 1.577, 1.857, 4.041 and $4.289 \mathrm{~min}$, and showed $9.61 \%$ degradation of TLM and $8.55 \%$ degradation of AEL in $10 \mathrm{ml} 0.1 \mathrm{~N} \mathrm{HCl}$ after the stress of $30 \mathrm{~min}$. Significant degradation was ( $6.72 \%$ of TLM and $8.89 \%$ of AEL) observed in $10 \mathrm{ml} 0.1 \mathrm{~N} \mathrm{NaOH}$ after the stress of $30 \mathrm{~min}$. Unidentified degradation peaks are (fig. 3) examined at Rt's of 1.106, 1.499 and $4.953 \mathrm{~min}$. TLM and AEL was liable to degradation of $5.3 \%$ and $6.07 \%$, respectively in $1 \mathrm{ml} 30 \%$ peroxide after stress of $30 \mathrm{~min}$ with unidentified degradation peaks (fig. 3) at Rt's of 1.083, 1.587, 2.758, and 5.088 min. Observed $9.37 \%$ degradation of TML and $9.61 \%$ degradation of AEL in thermal-induced conditions after stress of $30 \mathrm{~min}$. Rt's of degradation peaks (fig. 3) were 1.225, 1.587, 1.877, 2.818 and $4.375 \mathrm{~min}$ in thermal-induced conditions. Significant degradation $(7.15 \%$ of TLM and $7.53 \%$ of AEL) is also observed in sunlight after stress of $6 \mathrm{hr}$. Unidentified degradation peaks (fig. 3) were examined at Rt's of 1.050, 1.765 and $5.171 \mathrm{~min}$ in sunlight stress of $6 \mathrm{~h}$

\section{Robustness}

Investigated the robustness with the working TLM and AEL sample (TLM-40 $\mu \mathrm{g} / \mathrm{ml} ;$ AEL- $8 \mu \mathrm{g} / \mathrm{ml}$ ) by analysis at divergent temperatures $\left(23{ }^{\circ} \mathrm{C}, 25^{\circ} \mathrm{C}\right.$ and $\left.27{ }^{\circ} \mathrm{C}\right)$, at divergent methanol percentages $(45 \%$, $50 \%$ and $55 \%)$, at divergent flow rates $(0.9 \mathrm{ml}, 1.0 \mathrm{ml}$ and $1.1 \mathrm{ml}$ per a min) and at divergent $\mathrm{pH}$ units $(3.3,3.5$ and 3.7$)$. The estimates of system suitability parameters and their RSD's were done in all divergent conditions. 

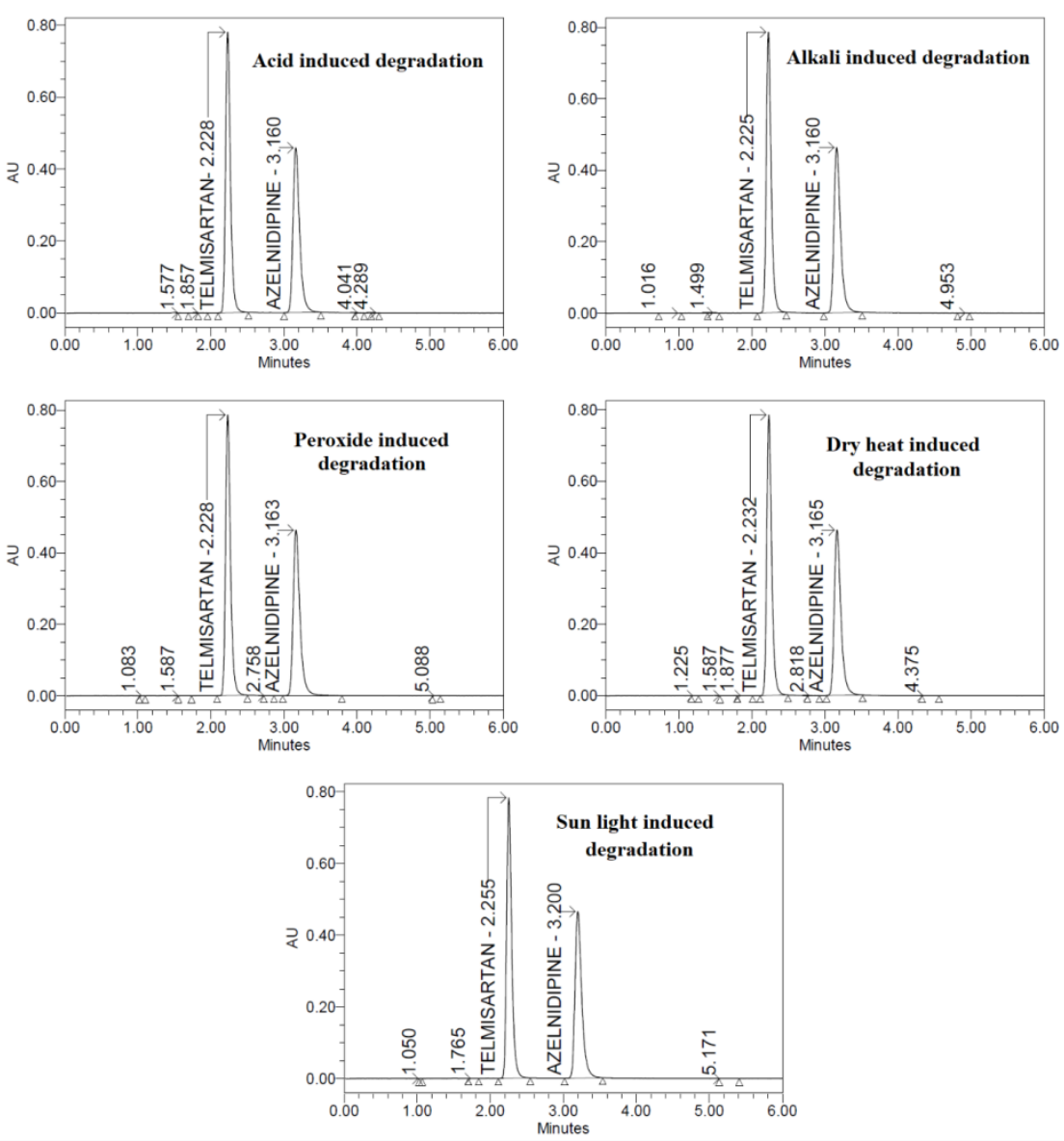

Fig. 3: Chromatograms corresponding to TLM and AEL degradation

Table 3: TLM and AEL combination HPLC evaluation conditions robustness

\begin{tabular}{|c|c|c|c|c|c|c|c|c|}
\hline \multirow{2}{*}{ Condition } & \multicolumn{4}{|l|}{ TLM } & \multicolumn{4}{|l|}{ AEL } \\
\hline & $\begin{array}{l}\text { Peak } \\
\text { response }\end{array}$ & Mean $^{*}$ assess & SD assess & $\begin{array}{l}\text { RSD } \\
\text { assess }\end{array}$ & $\begin{array}{l}\text { Peak } \\
\text { response }\end{array}$ & Mean ${ }^{*}$ assess & SD assess & $\begin{array}{l}\text { RSD } \\
\text { assess }\end{array}$ \\
\hline \multicolumn{9}{|l|}{ Methanol ratio } \\
\hline Optimized $50 \%$ vol & 3599678 & 3651851 & 62905 & 1.7 & 2797827 & 2834739 & 49611 & 1.8 \\
\hline Modified $45 \%$ vol. & 3634172 & & & & 2891135 & & & \\
\hline Modified 55\% vol. & 3721705 & & & & 2815255 & & & \\
\hline \multicolumn{9}{|l|}{ Column rate of flow } \\
\hline Optimized $1 \mathrm{ml} / \mathrm{min}$ & 3709678 & 3645351 & 59530 & 1.6 & 2827827 & 2874978 & 41502 & 1.4 \\
\hline Modified $0.9 \mathrm{ml} / \mathrm{min}$ & 3592203 & & & & 2905972 & & & \\
\hline $\begin{array}{l}\text { Modified } 1.1 \mathrm{ml} / \mathrm{min} \\
\mathbf{p H}\end{array}$ & 3634172 & & & & 2891135 & & & \\
\hline Optimized 3.5 unit & 3661916 & 3652866 & 16192 & 0.4 & 2906328 & 2915819 & 30556 & 1.0 \\
\hline Modified 3.3 unit & 3662512 & & & & 2949996 & & & \\
\hline Modified 3.7 unit & 3634172 & & & & 2891135 & & & \\
\hline \multicolumn{9}{|l|}{ Column temperature } \\
\hline Optimized $25^{\circ} \mathrm{C}$ & 3634172 & 3644265 & 58266 & 1.6 & 2891135 & 2880960 & 41563 & 1.4 \\
\hline Modified $23^{\circ} \mathrm{C}$ & 3591705 & & & & 2835255 & & & \\
\hline Modified $27^{\circ} \mathrm{C}$ & 3706919 & & & & 2916492 & & & \\
\hline
\end{tabular}

"Mean of 3 gauges; SD value-standard deviation for 3 gauges; RSD values-percentile standard deviation for 3 gauges

\section{DISCUSSION}

The increasing usage of TML and AEL for hypertension treatment has attracted our interest in developing a sensitive HPLC tool for evaluating TLM and AEL in bulk and tablet varieties. A series of trials of the current technique were worked out in consideration of the physical and chemical qualities of TLM and AEL, as well as information gathered thoroughly through the literature. During trials, the conditions considered were: different solvent compositions for mobile phase, detecting wavelength value, different columns, with diverse buffer agents and $\mathrm{pH}$ units [14].

Regarding linearity, projected HPLC evaluation conditions obtained upright $\mathrm{R}^{2}$ values of $>0.999$. Sensitivity was evidenced with low LOQ scores for TLM and AEL. The projected HPLC evaluation conditions were evidenced as precise since the RSD in repeatability is much less below $2.00 \%$. The projected HPLC evaluation conditions were evidenced as accurate since the percentage of TLM and AEL recovery 
is nearer to $100 \%$. The accuracy experiment findings of projected HPLC evaluation conditions also evidenced as selectivity since we found deprived of an interference with excipients. This projected HPLC evaluation conditions did well in determining the TLM and AEL deprived of any interference with degradants generated in acid, peroxide, dry heat, alkali, and sun light induced circumstances; thus, stability indicating feature evidenced [15-17]. No substantial disparity could be detected in the fallouts found out while analysing the working TLM and AEL sample at divergent temperatures $\left(23^{\circ} \mathrm{C}\right.$, $25^{\circ} \mathrm{C}$ and $\left.27^{\circ} \mathrm{C}\right)$, at divergent methanol percentages $(45 \%, 50 \%$ and $55 \%)$, at divergent flow rates $(0.9 \mathrm{ml}, 1.0 \mathrm{ml}$ and $1.1 \mathrm{ml}$ per a min) and at divergent $\mathrm{pH}$ units $(3.3,3.5$ and 3.7), thus evidenced robust.

\section{CONCLUSION}

The methodological functionalities of the proposed HPLC assessment settings (linearity, precision, as well as accuracy) were verified to be suitable for evaluating TLM and AEL mix. Finally, the suggested HPLC assessment settings are good in aspects of specificity, speed, simplicity, environmental impact, and cost efficiency and have optimal technical features for systematic analysis of TLM and AEL mix in bulk and tablet varieties.

\section{ACKNOWLEDGEMENT}

The authors express their thanks to Dean, HOD, principal and other teaching and non-teaching staff of University College of technology for providing facilities for carrying out the research work.

\section{FUNDING}

Nil

\section{AUTHORS CONTRIBUTIONS}

All the authors have contributed equally.

\section{CONFLICTS OF INTERESTS}

Declared none

\section{REFERENCES}

1. Destro M, Cagnoni F, Dognini GP, Galimberti V, Taietti C, Cavalleri C, Galli E. Telmisartan: just an antihypertensive agent? A literature review. Expert Opin Pharmacother. 2011;12(17):271935. doi: 10.1517/14656566.2011.632367, PMID 22077832.

2. Hwang YJ, Park JH, Cho DH. Activation of AMPK by telmisartan decreases basal and PDGF-stimulated VSMC proliferation via inhibiting the mTOR/p70s6K signaling axis. J Korean Med Sci. 2020;35(35):e289. doi: 10.3346/jkms.2020.35.e289, PMID 32893519.

3. Cho DH. Telmisartan inhibits nitric oxide production and vessel relaxation via protein phosphatase $2 \mathrm{~A}$-mediated endothelial no synthase-Ser1179 dephosphorylation. J Korean Med Sci. 2019;34(42):e266. doi: 10.3346/jkms.2019.34.e266, PMID 31674157.

4. Chen BL, Zhang YZ, Luo JQ, Zhang W. Clinical use of azelnidipine in the treatment of hypertension in Chinese patients. Ther Clin Risk Manag. 2015;11:309-18. doi: 10.2147/TCRM.S64288, PMID 25750535.

5. Bagheri M, Jahromi BM, Mirkhani H, Solhjou Z, Noorafshan A, Zamani A, Amirghofran Z. Azelnidipine, a new calcium channel blocker, promotes skin wound healing in diabetic rats. J Surg Res. 2011;169(1):e101-7. doi: 10.1016/j.jss.2011.02.039, PMID 21571319.

6. Nakamura T, Sugaya T, Kawagoe Y, Suzuki T, Ueda Y, Koide H, Inoue $\mathrm{T}$, Node K. Azelnidipine reduces urinary protein excretion and urinary liver-type fatty acid-binding protein in patients with hypertensive chronic kidney disease. Am J Med Sci. 2007;333(6):321-6. doi: 10.1097/MAJ.0b013e318065c254, PMID 17570983.

7. Telmisartan+azelnidipine, $1 \mathrm{mg} . c 0 \mathrm{~m} /$ generics/telmisartanazelnidipine-509412.

8. Yuvasri S, Murugan S, Vetrichelvan T. First-order derivative and UV-spectrophotometric methods for simultaneous determination of telmisartan and azelnidipine in bulk and tablet dosage form. Eur J Biomed PharmSci. 2021;8:290-4.

9. Kumar M, Chandra U, Garg A, Gupta P. A stability indicating RPHPLC method validation for simultaneous estimation of azelnidipine and telmisartan in a fixed-dose combination. Int J Pharm Sci Drug Res. 2021;13:288-94.

10. Kishore K, Somasekhar RK. Method development and validation for the simultaneous estimation of azelnidipine and telmisartan in pharmaceutical formulation by highperformance liquid chromatography. Boll Environ Pharmacol Life Sci. 2021;10:19-27.

11. Parikh MB, Dalwadi P, Dharu N. Stability indicating RP-HPLC method development and validation for the simultaneous estimation of telmisartan and azelnidipine in tablet dosage form. Int J All Res Ed Sci Method 2021;9:1082-90.

12. International conference on harmonization. ICH Stability testing of new drug substances and products. Vol. Q1A(R2); 2003.

13. International conference on the harmonization. ICH harmonized tripartite guideline. Validation of analytical procedures: text and methodology. Vol. Q2(R1); 2005.

14. Azim MdS, Mitra M, Parminder SB. HPLC method development and validation: a review. Int Res J Pharm. 2015;4:39-46.

15. Sonawane $S$, Jadhav $S$, Rahade $P$, Chhajed $S$, Kshirsagar $S$. Development and validation of a stability-indicating method for estimation of chlorthalidone in bulk and tablets with the use of experimental design in forced degradation experiments. Scientifica (Cairo). 2016;2016:4286482. doi: $10.1155 / 2016 / 4286482$.

16. Blessy M, Patel RD, Prajapati PN, Agrawal YK. Development of forced degradation and stability indicating studies of drugs-a review. J Pharm Anal. 2014;4(3):159-65. doi: 10.1016/ j.jpha.2013.09.003, PMID 29403878.

17. Bakshi M, Singh S. Development of validated stability-indicating assay methods--critical review. J Pharm Biomed Anal. 2002;28(6):1011-40. doi: 10.1016/s0731-7085(02)00047-x, PMID 12049968. 